\title{
Perjury in Early Tudor England
}

\author{
Paul Cavill* \\ Pembroke College, Cambridge
}

\begin{abstract}
The break with Rome was enforced through a nationwide programme of oath-taking. The Henrician regime resorted to oaths because they were already fundamental to the functioning of the polity. In the preceding half-century, activities as diverse as heresy prosecution, tax assessment and debt litigation depended upon oaths. Irrespective of their often mundane subject matter, oaths were held to be religious acts. Prolific oathtaking, however, led to frequent oath-breaking. Perjury was therefore a more pressing and broader concept than it is today. It was an offence against God, against oneself and against others. How this crime was prosecuted and punished sheds light on the intersection of religious doctrine, legal systems and social practice in pre-Reformation England. An analysis of perjury also draws attention to a jurisdictional shift that was underway before the Reformation. In 1485, church courts had exercised an extensive cognizance of perjury; by 1535, they no longer did. The most important factor contributing to this decline in ecclesiastical jurisdiction was the constraint imposed by common lawyers on what cases the church courts could hear. Common law defined the crime of perjury more narrowly than did canon law. Hence the contraction of the church's jurisdiction would alter how perjury was perceived.
\end{abstract}

Early Tudor England (1485-1535) was a polity and society built around the taking of oaths. Every adult from the monarch downwards swore oaths. Henry VIII took a keen interest in his coronation oath: he had it, he said, 'in remembraunce' when invoking his duty to administer justice in $1516 .{ }^{1}$ Treaties with other princes were made binding through religious rituals of reciprocal oath-taking with foreign ambassadors, which were afterwards authenticated as transumpts at the archbishop's command by public notaries. ${ }^{2}$ The king's subjects

* Pembroke College, Cambridge, CB2 1RF. E-mail: pc504@cam.ac.uk.

I thank Daniel Gosling, Shannon McSheffrey and Hillary Taylor for their help and two reviewers for their suggestions.

1 San Marino, CA, HL, MS Ellesmere 2654, fols 22 $2^{\mathrm{v}}-23^{\mathrm{r}}$; MS Ellesmere 2655, fol. $10^{\mathrm{r}} \mathrm{v}^{\mathrm{v}}$.

${ }^{2}$ London, BL, MS Add. 48012, fols $24^{\mathrm{r}}-27^{\mathrm{v}}$. 
took oaths of allegiance, to which could be added a requirement not to become the sworn retainers of anyone else. ${ }^{3}$ Upon assumption of office, royal servants took oaths of duty. Cardinal Wolsey swore the chancellor's oath on Christmas Eve 1515 after vespers in the chapel at Eltham Palace. ${ }^{4}$ Such oaths were tailored to the position held: the one taken by the sheriff of Cambridgeshire and Huntingdonshire added an undertaking to defend the privileges of Cambridge University. ${ }^{5} \mathrm{It}$ was not only the crown which exacted oaths: the practice was universal. Oaths promised the obedience of a citizen to the mayor, a tradesman to the masters of his company, a stipendiary priest to the parson and a monk to his abbot. A livery company could have sixteen different oaths. ${ }^{6}$ Furnishing such texts stimulated record-keeping, and oaths abound in the surviving books that belonged to government departments, urban corporations and private individuals.

Oaths were categorized either as affirmations (of a fact, as in testimony to a court) or as promises (of future performance, such as payment of a debt). ${ }^{7}$ They were an inescapable aspect of the mundane activities of buying and selling, family life, domestic and local government and law enforcement. They were a fundamental facet of the economy, essential in a commercial system that depended on trust. Alleging that someone 'woll pay no man his deutye' was thus interpreted as an accusation of habitual oath-breaking. ${ }^{8}$ Oaths were integral to the different legal systems that operated within the kingdom too. Social and public life depended on oath-taking. A fishmonger who had 'made a vowe to make no maner Othe Duryng his lyff (perhaps deliberately) rendered himself incapable of holding office and

3 Lorraine C. Attreed, ed., The York House Books, 1461-1490, 2 vols (Stroud, 1991), 1: 379-82; Gordon McKelvie, 'Henry VII's Letter to Carlisle in 1498: His Concerns about Retaining in a Border Fortress', NH 54 (2017), 149-66, at 165-6.

${ }^{4}$ Kew, TNA, C54/383, m. 31 ${ }^{\mathrm{d}}$.

5 Rosemary Horrox and P. W. Hammond, eds, British Library Harleian Manuscript 433, 4 vols (Gloucester, 1979-83), 3: 173-84, at 177.

6 T. F. Reddaway and Lorna E. M. Walker, The Early History of the Goldsmiths' Company, 1327-1509 (London, 1975), 212-21.

7 Andrew Chertsey, The Floure of the Commaundementes (London, 1510), fol. 23 ${ }^{\mathrm{r}}$; Barbara J. Shapiro, 'Oaths, Credibility and the Legal Process in Early Modern England: Part One', Law and Humanities 6 (2012), 145-78, at 148-51.

8 London, LMA, DL/C/B/043/MS09064/011, fol. 303; James Davis, Medieval Market Morality: Life, Law and Ethics in the English Marketplace, 1200-1500 (Cambridge, 2012), 71-3. 
thereby transgressed his obligations to his community. ${ }^{9}$ Because they were sworn at major moments in an individual's life - entering service, becoming free of one's hometown, joining a guild - oaths must have constituted rites of passage. Recourse was had to oaths in informal and spontaneous contexts as well. When threatened with the stocks, a servant who had 'meddyld' with a female counterpart said that he would marry her if their master would take an oath that 'she is a good mayde save for me', which the master instantly did, swearing 'so helpe me god and halydome and by this boke'. ${ }^{10}$

Early Tudor England functioned the way it did because of oaths. Yet the very extensiveness of swearing routinized the practice, potentially transforming it into an act undertaken casually or even falsely. Pervasive oath-taking entailed frequent oath-breaking. Circumstance, perception and pressure must have dictated whether oaths were treated as urgent and burdensome or as formulaic and vacuous. In 1516, the government's attempted reform of sheriffs' conduct focused on getting them to implement the contents of their oaths. ${ }^{11}$ Kings were notorious for breaking oaths made to other princes. In Utopia, Thomas More observed sarcastically how '[i]n Europe, of course, and especially in these regions where the Christian faith and religion prevail, the dignity of treaties is everywhere kept sacred and inviolable.' 12 Subjects sometimes behaved no better than their rulers. At the beginning of Henry VII's reign, the judges were debating how to alleviate disorder. The idea of peers taking an oath to uphold the law seemed pointless to Chief Justice Hussey, who recalled how on a previous occasion he had seen lords take a similar oath which they had then broken within the hour. ${ }^{13}$

But forswearing was not taken lightly. Offenders could be disgraced, punished or ostracized. In 1511, among the villagers of Littlebury in Essex, John Parkyn was 'defamed, held and reputed' to

9 LMA, COL/CA/01/01/003, fol. 80v' Susan Brigden, 'Religion and Social Obligation in Early Sixteenth-Century London', $P \& P 103$ (1984), 67-112, at 86-92.

${ }^{10}$ Hertford, Hertfordshire Archives and Local Studies (hereafter: HALS), ASA8/1, fol. $56^{\mathrm{v}}$.

11 Le P 2/1: 2579*. Le P is cited by document number.

12 Thomas More, Utopia, ed. George M. Logan and Robert M. Adams, rev. edn (Cambridge, 2002), 83; William Tyndale, The Practyse of Prelates (Antwerp, 1530), sigs $\mathrm{F}^{\mathrm{v}}-\mathrm{F} 8^{\mathrm{v}}$.

13 Year Books, Mich. 1 Hen. VII, plea 3. The Year Books are cited from the so-called 'vulgate edition': Les Reports des Cases, 11 vols (London, 1678-80). 
be a perjurer because he had given false evidence under oath against the parson; as a result, some parishioners there shunned Parkyn's company. ${ }^{14}$ To be called 'perjured' was seriously insulting; it could be a defamation worth suing over. ${ }^{15}$ People of good conversation, credit and substance were thought unlikely to lie under oath; conversely, that a couple got so drunk that they could hardly stagger home indicated a predisposition to perjury in the mind of a neighbour. ${ }^{16}$ In short, this was an age which saw oaths as assuring diligence, fidelity and truthfulness, yet also recognized that they were regularly broken. Perjury was thus an important concept in early Tudor England, where social practice, religious doctrine and legal structure intersected.

Early Tudor England also changed perjury. Conventionally, scholarship on early modern oath-taking and oath-breaking starts where this article stops: at the break with Rome. The succession and supremacy oaths of 1534 onwards usually constitute the point of departure and so subsequent developments are related to the Reformation. ${ }^{17}$ The state's increasing imposition of oaths thereafter is sometimes thought to have been counterproductive, to have stimulated dissimulation and equivocation, maybe even to have assisted in a societal shift from credulity to cynicism. ${ }^{18}$ The early modern period is also held to have exalted the autonomy of the lone conscience: 'the Reformation transformed an understanding of conscience as objective in nature, subject to the dictates of the Church, to subjective, as

${ }_{15}$ LMA, DL/C/0206, fols $35^{\mathrm{v}}-36^{\mathrm{r}}$.

15 LMA, DL/C/B/043/MS09064/011, fols 50 $0^{\mathrm{r}}, 51^{\mathrm{r}}, 62^{\mathrm{v}}-63^{\mathrm{r}}, 105^{\mathrm{r}}$; William H. Hale, ed., A Series of Precedents and Proceedings in Criminal Causes, extending from the Year 1475 to 1640; extracted from Act-Books of Ecclesiastical Courts in the Diocese of London (London, 1847), no. 305; Chichester, West Sussex RO (hereafter: WSRO), Ep.I/10/1, fol. $101^{\mathrm{r}}$; Ep.I/10/4, fol. $47^{\mathrm{r}}$.

16 TNA, STAC2/20/195; HALS, ASA8/1, fol. 20v; Alexandra Shepard, Accounting for Oneself: Worth, Status, and the Social Order in Early Modern England (Oxford, 2015), $133-43$.

17 The principal account is Jonathan M. Gray, Oaths and the English Reformation (Cambridge, 2013).

18 These possibilities are explored in John Spurr, 'Perjury, Profanity and Politics', Seventeenth Century 8 (1993), 29-50; idem, 'A Profane History of Early Modern Oaths', TRHS 6th series 11 (2001), 37-63; Harald E. Braun and Edward Vallance, eds, Contexts of Conscience in Early Modern Europe, 1500-1700 (Basingstoke, 2004); Edward Vallance, Revolutionary England and the National Covenant: State Oaths, Protestantism and the Political Nation, 1553-1682 (Woodbridge, 2005); Conal Condren, Argument and Authority in Early Modern England: The Presupposition of Oaths and Offices (Cambridge, 2006). 
individuals had to rely on their own understanding of how to behave morally ... cast adrift from an obvious institutional framework' ${ }^{19}$ Yet the early Tudor half-century had already altered the structure within which oaths were enforced. In 1485, church courts had exercised an extensive cognizance of perjury; by 1535 , they no longer did. Obviously, the Reformation cannot explain this decline; nor, given the chronology of developments, can the break with Rome.

This article seeks to account for what had happened. To do so, it samples the records of church, common-law and conciliar courts, and it explicates the expert legal literature on the subject. ${ }^{20}$ The article identifies two definitions of perjury, as either breaking an oath or forswearing in court. It illustrates how these interpretations were applied in the different types of court. It explores the interaction between the needs of litigants, the interests of legal practitioners and the technicalities of procedure. The article shows how perjury came increasingly under the jurisdiction of royal courts as the crime drifted out of the church's orbit. It points to the role of common lawyers in curtailing ecclesiastical jurisdiction and emphasizes their non-judicial understanding of conscience. In consequence, it is proposed, the legally enforceable definition of perjury narrowed. The post-Reformation legal system did not fully comprehend perjury in its broadest sense. This omission, it is implied, may have contributed to the elevation of individual conscience and to the growing concern about the integrity of oath-taking that scholars have identified. Thus it is suggested that early Tudor England began to laicize the crime of perjury.

Oaths were a doctrinal matter. ${ }^{21}$ Taking an oath was supposed to be an act of faith, of worship even, a kind of latria. The theology of swearing was based on the teaching of Augustine of Hippo. ${ }^{22}$ It

\footnotetext{
19 Andrew Hadfield, Lying in Early Modern English Culture: From the Oath of Supremacy to the Oath of Allegiance (Oxford, 2017), 48, 308. That early modernists have underestimated the continuing influence of the medieval casuistical tradition, however, is argued in Emily Corran, Lying and Perjury in Medieval Practical Thought: A Study in the History of Casuistry (Oxford, 2018), 9-13, 132-42, 150-1.

20 The seminal piece is R. H. Helmholz, 'Assumpsit and fidei laesio', Law Quarterly Review 91 (1975), 406-32.

21 R. H. Helmholz, The Spirit of Classical Canon Law (Athens, GA, 1996), 146-52; Gray, Oaths, 17-50.

22 Augustine, Sermo 180 (PL 38: 972-9); De mendacio (PL 40: 487-517); Contra mendacium (PL 40: 517-48); Corran, Lying and Perjury, 45-8.
} 
embraced the gamut of swearing, encompassing vows and profanities as well as oaths. No matter what its subject was, an oath was inherently religious: the person taking it called God to witness to the sincerity and truthfulness of the matter. This spiritual character was often reinforced through swearing on a sacred object, especially the gospels. ${ }^{23}$ Books of oaths incorporated appropriate texts on which to swear: in a volume prepared for a customs house, the gospel cursus prefaced the oath taken by shipmasters transporting wool to Calais. ${ }^{24}$ In the Exchequer in the 1530s, royal tenants swore succession oaths upon a book containing twelfth-century gospel lessons, to the back cover of which a gilt crucifix was, and still is, nailed: a tangible reminder of the ultimate power underwriting such promises. In courts of law, the volume upon which oaths were taken was known as 'the jury book', and it too might be paired with a crucifix. ${ }^{25}$

Swearing too readily was, however, believed to be a slippery slope to swearing falsely. Oaths were supposed to be taken considerately rather than rashly, out of necessity for serious matters, not habitually over trifles. To swear to a moot point or to an estimate was inadvisable. ${ }^{26}$ Profane swearing was a mortal sin, graphically imagined as crucifying Christ anew. ${ }^{27}$ It was, however, not yet an offence that provoked society into concerted action. Maybe blaspheming was less prolific in the early Tudor period than it would become later; maybe, before the Reformation, God's vengeance was expected to alight on the individual rather than on the covenanted nation. Spiritual guides pointed to manifestations of divine punishment: twenty-five miles from London, on the highway to Cambridge, a massive haemorrhage was the fitting end for swearing by God's blood. ${ }^{28}$ In sum, to swear

23 William Lyndwood, Provinciale (Oxford, 1679), 108o, 110h, 110-11r.

24 BL, MS Royal 9 A XII, fols $15^{\mathrm{r}}-16^{\mathrm{v}}$. The cursus excerpted the story of Christ's birth, death and resurrection. The scriptural content of oath books is discussed in Eyal Poleg, Approaching the Bible in Medieval England (Manchester, 2013), 84-92.

${ }_{25}$ BL, MS Stowe 15, fols $8^{\mathrm{v}}-9^{\mathrm{r}}$; Kingston upon Thames, Kingston History Centre, KD3/ 1/1, 45 (borough inventory, 1514); Susanne Brand, 'The Fifteenth-Century Accounts of the Undersheriffs of Middlesex: An Unlikely Source for Legal History', in David Ibbetson, Neil Jones and Nigel Ramsay, eds, English Legal History and its Sources: Essays in Honour of Sir John Baker (Cambridge, 2019), 159-75, at 170.

26 Lyndwood, Provinciale, 116a; Chertsey, Floure, fol. 24 ${ }^{\mathrm{r}}$; J. H. Baker, ed., Reports of Cases by John Caryll, 2 vols, SelS 115-16 (London, 1999-2000), 1: 27; L\&P 4/2: 4631.

27 Stephen Hawes, The Conuercyon of Swerers (London, 1509), sigs A3 $3^{\mathrm{r}}, \mathrm{A} 7^{\mathrm{r}}$.

28 Richard Whitford, $A$ Werke for Housholders (London, 1530), sigs C ${ }^{\mathrm{v}}-\mathrm{C} 4^{\mathrm{r}}$. 
wrongly was to traduce God, imperil one's soul and risk retribution. Oaths were deadly serious.

But to refuse to swear in any circumstance was an excessively literal construal of the second commandment (in the English preReformation, or Catholic and Lutheran, numbering) and of the Sermon on the Mount (Matt. 5: 34-7). ${ }^{29}$ Rejection of oath-taking was treated as heresy and associated with Lollardy. According to Alice Walker, her husband Thomas refused to seal agreements with an oath and rebuked her for wishing to swear. ${ }^{30}$ A suspect might be asked 'whether someone ought to swear to say the truth over certain articles concerning the honour of God and the church and the health of his soul if he were ordered to by a legitimate judge'. ${ }^{31}$ Misbelief was akin to perjury, since both traduced God. A heretic and a perjurer once performed penance together at Paul's Cross during the sermon. ${ }^{32}$ Oath-breakers and heretics had faithlessness in common. When a member of the Shearers' Company was elected alderman in 1514, London's governors required him to transfer to a more exalted livery company. To a disgruntled shearer, his former brother was 'periured' and 'worse thene an heretyk' for breaking his oath to the Shearers' Company. ${ }^{33}$

As Augustine had taught, rules governing swearing constrained those seeking oaths from others. To require an oath unnecessarily when you believed someone anyway was a pardonable sin; to do so knowing that a person would forswear himself was a mortal one, the individual's sin rebounding on you. ${ }^{34}$ When Margaret Webb produced honest female neighbours as compurgators, the judge dismissed her without taking her oath. ${ }^{35}$ Those in positions of authority were expected to avoid giving occasion for perjury. In 1510, the Mercers'

29 For the alternative numberings, see Jonathan Willis, The Reformation of the Decalogue: Religious Identity and the Ten Commandments in England, c.1485-1625 (Cambridge, 2017), 28-36.

30 Lyndwood, Provinciale, 298-9e; Dublin, Trinity College, MS 775, fol. $124^{\mathrm{r}}$ (London, 1511); Shannon McSheffrey and Norman Tanner, eds, Lollards of Coventry, 1486-1522, Camden Society 5th series 23 (London, 2003), 95, 311.

31 HALS, ASA7/1, fol. 42A (John Woodward of Watford, 1527); John Foxe, Actes and Monuments, 2 vols (London, 1583), 2: 1102 (art. 41).

32 Lyndwood, Provinciale, 55r, 56b; A. H. Thomas and I. D. Thornley, eds, The Great Chronicle of London (London, 1938), 262.

33 LMA, COL/CA/01/01/002, fol. $187^{\mathrm{r}}{ }^{\mathrm{v}}$.

34 Augustine, Sermo 180.10 (PL 38: 978); Chertsey, Floure, fols 23v, $208^{\mathrm{v}}$.

35 LMA, DL/C/B/043/MS09064/011, fol. $137^{\mathrm{r}}$. 
Company of London decided that it would no longer admit as apprentice anyone who looked to be under the age of sixteen, even if he and his friends offered to swear that he was in fact old enough, for fear of encouraging perjury. ${ }^{36}$ The same principle could be applied to criticize royal policy when it tempted people to forswear. In the later years of Henry VII's reign, preachers attacked the crown's encouragement of promoters (private individuals who prosecuted offences for a share of the statutory penalty) on this ground. ${ }^{37}$

That oaths were religious acts raised the question of how jurisdiction over perjury should be distributed between the different legal systems. In the Provinciale, written in the 1420s but much consulted during the early Tudor period, the canonist William Lyndwood had described perjury as a 'mixed crime' over which both ecclesiastical and secular courts exercised jurisdiction. ${ }^{38}$ This joint competence was complicated by the fact that the two legal systems defined perjury differently. This divergence may have arisen because the offence contravened two of the Ten Commandments: the second (against taking the Lord's name in vain) and the eighth (against bearing false witness). One commandment belonged to the first table (concerning humanity's duty to God) and the other to the second table (concerning people's relations with each other). Nevertheless their import was merged: a devotional text that worked its way through the Decalogue, upon reaching the eighth commandment, rather than repeat its material referred back to the discussion of the second. Illustrations of offences against each commandment collapsed the distinction, with witnessing falsely being discussed under the second, as well as the eighth, commandment. ${ }^{39}$

Treating perjury as both lying under oath and violating an oath potentially conferred on the church jurisdiction over a vast number of agreements and undertakings. In fact, common lawyers had long

\footnotetext{
36 Lætitia Lyell and Frank D. Watney, eds, Acts of Court of the Mercers' Company, 14531527 (Cambridge, 1936), 382.

37 Thomas and Thornley, eds, Great Chronicle, 335, 337; e.g. Guy Parsloe, ed., Wardens' Accounts of the Worshipful Company of Founders of the City of London, 1497-1681 (London, 1964), 39-40 (a forsworn informant in 1514).

38 Lyndwood, Provinciale, 315o. Other glosses, however, referred to perjury as an ecclesiastical crime that pertained to the church: ibid. $31600,322 \mathrm{~m}$. The Provinciale was printed in 1483, 1501, 1506 and 1525 .

39 Whitford, Werke, sig. E4 ${ }^{\mathrm{r}}$; Chertsey, Floure, fol. $22^{\mathrm{r}}$.
} 
feared that, if this definition were accepted, then 'every lay contract would be determined in court Christian' ${ }^{40}$ Not all promises were oaths, however. It was a legitimate defence before a church court to acknowledge an agreement or injunction but to deny having sworn to perform or abide by it. ${ }^{41}$ While a simple promise might bind in the court of conscience, what made it actionable in the external forum (the church court) was solemnization through an oath. ${ }^{42}$ The rule was no oath, no perjury. Hence Lyndwood maintained that, while the two legal systems shared jurisdiction over perjury, that of the church was superior, because it alone could resolve any doubt over the validity of an oath. ${ }^{43}$

Common law adopted a much narrower definition of perjury, based solely on the eighth commandment. In a reading at Gray's Inn in 1514, the bencher (or senior member) John Hales explained to his audience of students how the realm's laws were 'derived from and began with the law of God, namely the law of Moses' ${ }^{44}$ He then set out how responsibility for enforcing the Ten Commandments was divided between the spiritual and temporal jurisdictions. A murderer who broke the fifth commandment and a thief who broke the seventh 'would be punished by our law'; in the case of an adulterer who broke the sixth commandment, 'the punishment appertains to the spiritual law'. Secular justice enforced the eighth commandment: 'if anyone were sworn and were to bear false witness ... then he would be punished by the common law through attaint'. Hales's example was limited to legal proceedings. The crime of perjury was thus distinguished from general forswearing as referring to an oath taken in a court of record.

The limitation on who swore further narrowed the scope of perjury at common law. Only jurors could commit common-law perjury, because, as the etymology implies, it was they who were

\footnotetext{
${ }^{40}$ Year Books, Mich. 2 Hen. IV, plea 45, per Hankford.

41 WSRO, Ep.I/10/2, fol. 89v; York, BIA, CP.G.306; J. T. Fowler, ed., Acts of Chapter of the Collegiate Church of SS. Peter and Wilfrid, Ripon, A.D. 1452 to A.D. 1506, SS 64 (Durham, 1875), 121, 185; Helmholz, 'Assumpsit', 419-20; Ian Forrest, Trustworthy Men: How Inequality and Faith made the Medieval Church (Princeton, NJ, 2018), 44.

42 Lyndwood, Provinciale, 108q, 117a; LMA, DL/C/0206, fols 250v-252v; A. Percival Moore, ed., 'Proceedings of the Ecclesiastical Courts in the Archdeaconry of Leicester, 1516-1535', Associated Architectural Societies' Reports and Papers 28 (1905-6), 117220, 593-662, at 159; Christopher St German, Doctor and Student, ed. T. F. T. Plucknett and J. L. Barton, SelS 91 (London, 1974), 232.

43 Lyndwood, Provinciale, 116a, 315o.

44 London, Gray's Inn, MS 25, fol. $290^{\mathrm{r}}$.
} 
formally sworn. Witnesses did give evidence under oath, but for the information of the jury, not as matter of record. ${ }^{45}$ In common-law theory, the jurors were the proper witnesses. In the mid-fifteenth century, Sir John Fortescue had boasted that common law was superior to civil law because it depended on twelve sworn men rather than on two (the number of witnesses required in civil, and also in canon, law). ${ }^{46}$ The writ of attaint to which Hales referred could thus only be sued against jurors. So, when Thomas Baker gave false testimony for a plaintiff in the sheriffs' court at York in 1526, the defendant prosecuted him for perjury in the archbishop's court, producing members of the original jury as witnesses. The church court might claim jurisdiction because Baker had taken an oath upon a book of hours before testifying. ${ }^{47}$

\section{III}

Both secular and ecclesiastical legal systems sought to deter perjury. Royal government envisaged perjury as harming the king's subjects and displeasing God. Legislative remedies concentrated on common-law juries. In the belief that poorer jurors forswore for money, property qualifications were revised upwards, but then again downwards, once it transpired that in some places not enough people met the threshold. The procedure in attainting juries was reformed and also extended to London, whose inhabitants were thought particularly prone to perjury. ${ }^{48}$ In June 1517 , the popular preacher Rowland Phillips, vicar of Croydon, got into trouble 'for thinges vtterid in his sermon, concernynge Juries and atteyntes'. ${ }^{49}$ The new legislation was certainly controversial: introduced in 1495, it was amended during passage so as to require renewal in the next parliament. Three times, the measure came back for renewal, on each

\footnotetext{
45 John Fortescue, De laudibus legum Anglie, ed. S. B. Chrimes (Cambridge, 1942), 5863; Christopher St German, Salem and Bizance (London, 1533), sigs G8 ${ }^{\mathrm{v}}-\mathrm{H} 1^{\mathrm{v}}$. Justices exercised discretion over whether evidence was given under oath: TNA, STAC2/18/1; J. H. Baker, ed., Reports of Cases from the Time of King Henry VIII, 2 vols, SelS 120-1 (London, 2003-4), 2: 317-18.

46 Fortescue, De laudibus legum Anglie, ed. Chrimes, 42-3, 66-79.

47 BIA, CP.G. 181.

4811 Hen. VII cc.21, 24, 26; TNA, C1/109/26; Baker, ed., Reports of Henry VIII, 1: 667; Penny Tucker, Law Courts and Lawyers in the City of London, 1300-1550 (Cambridge, 2007), 38-9, 224-30, 345-9.

49 HL, MS Ellesmere 2652, fol. 10v . In the month after 'Evil May Day', the king's council may have been alert to contentious preaching.
} 
occasion having another limiting clause added, until it expired in 1512; it was revived in 1532, but again for a fixed term. ${ }^{50}$ Perhaps the penalties in attaint seemed too draconian. After all, jury service was imposed and defeated parties could prove vindictive; it was sometimes difficult to tell what the correct verdict should have been. ${ }^{51}$

Attaint came to matter less over the early Tudor period, because increasingly perjury was prosecuted before the conciliar courts instead. ${ }^{52}$ This jurisdiction extended to criminal cases and others to which the king was party. It outgrew any statutory basis to operate as an unmediated emanation of royal authority. ${ }^{53}$ The conciliar courts dealt with common-law juries, upon referral by justices as well as upon private bill. ${ }^{54}$ They also heard complaints against parties and witnesses. ${ }^{55}$ Their jurisdiction extended to perjury committed in the ecclesiastical system. Compurgators who, before the ordinary, had untruthfully declared a clerk convict innocent of rape were prosecuted before the council. ${ }^{56}$ In the 1520s, an Essex vicar complained that a neighbouring parson had hired eight men to give false evidence in the archbishop of Canterbury's court, ' $[\mathrm{t}] \mathrm{o}$ the gret Joperdie of the seid parsone and parjured persons yf Condinge ponysment and pennaunce should not be hade'. ${ }^{57}$

The conciliar courts punished perjury through public shaming in a prominent place at a busy time. Offenders wore papers on their heads announcing 'in great lettres' that ' $[t]$ hes men bene wylfully periured'. Such a penalty was described in decrees as penance. ${ }^{58}$ As such, it resembled the sentences imposed in church courts, which on occasion also ordered perjurers to wear papers proclaiming their offence. This punishment was at the discretion of the chancellor, a prelate until

5012 Hen. VII c.2; 19 Hen. VII c.3; 1 Hen. VIII c.11; 23 Hen. VIII c.3.

51 Baker, ed., Reports of Caryll, 1: 120-1.

52 John Baker, OHLE, 6: 1483-1558 (Oxford, 2003), 371-3.

5311 Hen. VII c.25 (expired 1504); TNA, STAC1/2/124; C. B. Bayne and William H. Dunham, eds, Select Cases in the Council of Henry VII, SelS 75 (London, 1958), 71, 76.

54 TNA, DL5/2, fols $103^{\mathrm{v}}$, $104^{\mathrm{v}}$; DL5/4, fols $122^{\mathrm{v}}, 135^{\mathrm{v}}$; KB9/453/119; STAC2/20/ 126; BL, MS Lansdowne 639, fol. $45^{\mathrm{r}}$; HL, MS Ellesmere 2768, fol. 23 ${ }^{\mathrm{v}}$; Bayne and Dunham, eds, Select Cases in the Council, 62-77a.

55 Such as TNA, STAC2/15/125-6 (defendant in Chancery); STAC2/25/74 (witnesses at assizes); STAC2/26/95 (witnesses in King's Bench).

56 BL, MS Lansdowne 639, fol. $48^{\mathrm{r}}$.

57 TNA, STAC2/9/159.

58 TNA, C193/142, fol. $46^{\mathrm{r}}-^{\mathrm{v}}$; BL, MS Lansdowne 639, fols $47^{\mathrm{v}}, 48^{\mathrm{v}}-49^{\mathrm{r}}$; HL, MS Ellesmere 2652, fol. $10^{\mathrm{v}}$. 
1529. Apparently, it was imposed by Wolsey to such great effect that 'in his tyme' perjury 'was lesse used'. ${ }^{9}$ According to George Gower, wearing papers would mean that he would 'no more be Reputed trewe or honest or taken In to any feloship or company', forcing him 'to fle the kings Realme neuer to be sene within the land'. Gower may not have been exaggerating much: for a member so to be punished could cause 'grete infamy ... to the hoole body' of his company. ${ }^{60}$ The implication of being forsworn made the insult 'papirid knave' defamatory. ${ }^{61}$ This conflation of punishment and penance reflected a general understanding of perjury as an offence against God.

Nevertheless, the rationale differed somewhat between the legal systems and between different royal courts. Like the church courts, Chancery acted out of concern for the offender's soul. Yet in describing perjury as being 'against conscience', petitioners were more concerned with an abstract sense of right and wrong. Their bills emphasized the enormity of the offence, less commonly the detrimental effect on the offender ('the losse of the lyffe eternalle'). ${ }^{62}$ In Star Chamber, an answer might reply that a bill had not shown that 'by reasoune of the othe' taken by the defendant the complainant 'is anie waise dampnifyed'. ${ }^{63}$ Only damage caused to others, not to oneself, by forswearing would have justified this case being heard. The Essex vicar was thus unusual in asking for penance as well as punishment. The displeasure caused to God aggravated the offence and made a punishment appropriate that was not only public but also penitential.

Church courts made greater use of oaths than did any other legal system. Every role, whether accused, party, compurgator, witness, executor, proctor, summoner or excuser of an absence, required them. ${ }^{64}$ Such oaths were more than procedural devices: they could prove determinative where no evidence was available (such as over

59 HALS, ASA7/1, fol. 26; Charles L. Kingsford, ed., Chronicles of London (Oxford, 1905), 208; Baker, ed., Reports of Henry VIII, 2: 332; Henry Ellis, ed., Hall's Chronicle (London, 1809), 585.

60 TNA, SP1/70, fol. $163^{\mathrm{v}}$ (L\&P 5: 1176); Matthew Davies, ed., The Merchant Taylors' Company of London: Court Minutes, 1486-1493 (Stamford, 2000), 237.

${ }^{61}$ HALS, ASA7/2, fol. 41 .

62 TNA, C1/410/46.

63 TNA, STAC2/22/269; STAC2/18/243; STAC2/22/203.

${ }^{64}$ Lyndwood, Provinciale, 177m, 254f, 298p; Helmholz, Spirit, 145, 152-61; R. H. Helmholz, OHLE, 1: The Canon Law and Ecclesiastical Jurisdiction from 597 to the 1640s (Oxford, 2004), 334-6. 
a clandestine marriage contract). ${ }^{65}$ Perjury was one of the courts' two disciplinary terms, alongside contumacy. Refusal to swear to perform penance was contumacy; failure to carry out the penance that you had sworn to perform was perjury. Breaking an injunction no longer to consort with someone with whom you were suspected of dallying was also perjury, on account of your prior oath to comply. Perjury in court entailed giving sworn testimony that proved false: for instance, denial under oath of carnal knowledge when your sexual partner confessed. ${ }^{66}$ Judicial oaths were not necessarily taken with especial seriousness; they might instead have prompted legalistic responses. A perjured witness in a testamentary case had been persuaded that an oath taken before the bishop of Exeter outside his diocese 'was as noe othe before god nor cold touch him in lawe'. ${ }^{67}$

Church courts concerned themselves with perjury committed in ecclesiastical contexts, such as a churchwarden's false presentment at a visitation. ${ }^{68}$ Religious institutions that were secular lords might exercise a wide jurisdiction over perjury. The archdeaconry of St Albans inquired into perjury committed in the abbey's manor courts and inferior ecclesiastical courts. It also enforced non-judicial oaths, in one case determining whether a defendant had sworn conditionally (as he alleged) or absolutely. ${ }^{69}$ Perjury committed in royal courts arguably lay within the remit of church courts. In 1521, the commissary court of Chichester accepted a complaint from John Lee that Richard Humfrey was perjured because he had falsely presented Lee to secular justices for assault. ${ }^{70}$ This case appears on one of the last pages of the act book and so its later course is unknown, which is disappointing because common lawyers denied the church's jurisdiction in such circumstances. ${ }^{71}$

65 Lyndwood, Provinciale, 20-1h, 48s, 76n; WSRO, Ep.I/10/1, fols 68v, 100 ; Moore, ed., 'Proceedings in Leicester', 621.

${ }^{66}$ Hale, ed., Precedents, nos 93, 131, 146; Forrest, Trustworthy Men, 58-9.

67 TNA, STAC2/22/225.

68 WSRO, Ep.I/10/2, fols $90^{\mathrm{r}}$, 93 ${ }^{\mathrm{r}}$; E. M. Elvey, ed., The Courts of the Archdeaconry of Buckingham, 1483-1523, Buckinghamshire Record Society 19 (n.pl., 1975), 257.

${ }^{69}$ HALS, ASA7/1, fols $54^{\mathrm{v}}, 58^{\mathrm{v}}, 59^{\mathrm{v}}$.

70 WSRO, Ep.I/10/2, fol. $135^{\mathrm{v}}$.

71 Baker, ed., Reports of Caryll, 1: 382; Margaret McGlynn, ed., The Rights and Liberties of the English Church: Readings from the Pre-Reformation Inns of Court, SelS 129 (London, 2015), 125, 163; Anthony Fitzherbert, La Nouel natura breuium (London, 1534), fol. 44 ${ }^{\mathrm{r}}$. 


\section{IV}

The principal factor in the contraction of ecclesiastical jurisdiction was the reduction in one type of case. In 1485, one of the commonest cases in church courts was 'breach of faith' (fidei laesio). ${ }^{72}$ Pledging your faith was like swearing an oath: according to Lyndwood, your faith substituted for the sacred object upon which an oath was taken. Hence breaching your faith was equivalent to breaking your oath. ${ }^{73}$ Thus some church courts treated the terms 'breach of faith' and 'perjury' as interchangeable. ${ }^{74}$ Any lawful undertaking was covered, including promises to observe corporate ordinances, honour pensions and abide by arbitrators' awards. ${ }^{75}$ London's hat-makers envisaged the bishop judging violations of their ordinances; following the craft's merger with the Haberdashers' Company, however, members found themselves prosecuted in the consistory court for perjury by the larger organization. ${ }^{76}$ Promises of service that could have been enforced under labour legislation were also broached. ${ }^{77}$ The majority of cases concerned things owed: usually a sum of money (seldom large), and also goods and chattels, including clothing, animals, crops, even bulbs of garlic. A rural deanery could thus become the principal forum for servicing small debt claims. ${ }^{78}$

Most breach of faith cases were brought by private parties rather than by the court itself. Hence the church's jurisdiction over perjury was exercised more on the instance, than on the office, side. ${ }^{79}$

72 There are complementary analyses of breach of faith, in point of law and as social practice, in Helmholz, OHLE, 1: 358-68; Forrest, Trustworthy Men, 33-62.

73 Lyndwood, Provinciale, 108o, 110-11r, 315p.

74 WSRO, Ep.I/10/1, fols $1^{\mathrm{r}}-117^{\mathrm{v}}$; Moore, ed., 'Proceedings in Leicester', 605, 619, 625, 645; Elvey, ed., Courts of Buckingham, 75-204; Forrest, Trustworthy Men, 44-5, 370 n. 73.

75 Hale, ed., Precedents, nos 17, 68, 75; LMA, DL/C/B/043/MS09064/011, fol. 39; BIA, CP.G.189A; Helmholz, 'Assumpsit', 410-11; Forrest, Trustworthy Men, 39, 56$8,60-1$.

${ }^{76}$ London, Guildhall Library, CLC/L/HA/A/009/MS15838, fols $11^{\mathrm{r}}-16^{\mathrm{v}}$; LMA, DL/C/ 0206, fols $293^{\mathrm{r}}-294^{\mathrm{r}}, 301^{\mathrm{r}}-302^{\mathrm{r}}, 317^{\mathrm{r}}-321^{\mathrm{v}}$; TNA, C1/302/25.

77 WSRO, Ep.I/10/1, fol. $3^{\text {r }}$; Hale, ed., Precedents, no. 46; Forrest, Trustworthy Men, 38.

78 L. R. Poos, ed., Lower Ecclesiastical Jurisdiction in Late-Medieval England: The Courts of the Dean and Chapter of Lincoln, 1336-1349, and the Deanery of Wisbech, 1458-1484, RSEH n.s. 32 (Oxford, 2001), l, liv, lvi, lxv, 300, 423, 543.

79 Hale, ed., Precedents, nos 177, 238, 267; Elvey, ed., Courts of Buckingham, 135; Helmholz, 'Assumpsit', 411-12. Office cases could be initiated or formally promoted by individuals: Hale, ed., Precedents, no. 272; Moore, ed., 'Proceedings in Leicester', 619, 625. 
Through breach of faith, church courts offered an effective means of enforcing a range of agreements. It was, for example, possible to sue a surety for another person's debt. ${ }^{80}$ Some defendants confessed what they owed straight away, submitted themselves and re-promised performance on pain of excommunication (although poverty could still prevent them from satisfying the other party). ${ }^{81}$ If not, then the standard criterion of proof was two witnesses; additionally, written evidence could be produced. ${ }^{82}$ While judges in theory punished the breach of faith rather than the non-payment, they usually did so by requiring the defendant to honour the debt. Often, they assigned no other penance. ${ }^{83}$ Awards could require payment in a week's time, but also by instalment, taking account of the defendant's means. ${ }^{84}$ Summoners serving citations might collect moneys owing and payments were also made in court. ${ }^{85}$

Breach of faith bulked large in the business of church courts at the beginning of our period, yet by its end had almost disappeared. This trend was first detected in the diocese of Canterbury, where cases increased over the second half of the fifteenth century and then declined from the turn of the sixteenth century onwards. In the consistory court, the number of cases rose from 150 in 1454 to peak in 1491 at 684 , but dwindled to a mere four in $1535 .{ }^{86}$ A reduction has since been observed in church courts in eight other dioceses. The number of cases in Hereford's consistory court in 1509-10 was only one-fifth of what it had been in 1497-8. Even in Chichester, where church courts thrived under Bishop Sherborn (1508-36), breach of faith cases shrank. ${ }^{87}$ The instance book of the archdeaconry

\footnotetext{
${ }^{80}$ WSRO, Ep.I/10/1, fol. 7v; BIA, CP.G.69; CP.G.107; Forrest, Trustworthy Men, 54-6.

81 WSRO, Ep.I/10/1, fols $4^{\mathrm{r}}, 13^{\mathrm{v}}, 60^{\mathrm{v}}, 66^{\mathrm{r}}, 73^{\mathrm{r}}$.

82 Lyndwood, Provinciale, 113d; BIA, CP.G.17; CP.G.100; WSRO, Ep.I/10/1, fol. 96;

Hale, ed., Precedents, no. 95; Helmholz, 'Assumpsit', 410.

${ }^{83}$ Helmholz, 'Assumpsit', 424-5; Forrest, Trustworthy Men, 36-7.

84 Elvey, ed., Courts of Buckingham, 167; Fowler, ed., Acts of Ripon, 267.

85 WSRO, Ep.I/10/1, fols $37^{\mathrm{v}}, 48^{\mathrm{r}}$.

86 Brian L. Woodcock, Medieval Ecclesiastical Courts in the Diocese of Canterbury (London, 1952), 84, 89-92, 109-10.

87 Helmholz, 'Assumpsit', 406-7, 426-8; Ralph Houlbrooke, Church Courts and the People during the English Reformation, 1520-1570 (Oxford, 1979), 39; Richard M. Wunderli, London Church Courts and Society on the Eve of the Reformation (Cambridge, MA, 1981), 104-5, 108; Stephen J. Lander, 'The Diocese of Chichester 1509-1558: Episcopal Reform under Robert Sherburne and its Aftermath' (PhD thesis, University of Cambridge, 1974), 39.
} 
of St Albans running from 1515 to 1543 contains only one such case (from 1532). ${ }^{88}$ There does not seem to be an endogenous explanation for this decline. The interests of those staffing church courts lay in sustaining a source of income; indeed, according to a critic, perjury cases were 'only stuff to geate money for thaduocates and proctours' ${ }^{89}$ External factors must be considered instead.

Jurisdiction over breach of faith depended upon people choosing to bring cases before church courts. The earlier growth may have occurred because business was being transferred from manor courts, whose effectiveness was declining as seigneurial authority over tenants weakened. ${ }^{90}$ If people were now choosing to sue elsewhere, then possible beneficiaries could have been borough courts, for it would be to these courts that much of the growing volume of debt litigation would later be directed. ${ }^{91}$ The court books of early Tudor Ipswich, for example, reveal a jurisdiction servicing contractual and debtrelated claims from the town and hinterland regularly and flexibly. There an obligor who had honoured someone else's debt could obtain redress; the central common-law courts had barely begun to offer relief in such circumstances. ${ }^{92}$ Much of London's breach of faith business might have been absorbed by civic courts; without their records, however, it is impossible to be sure. ${ }^{93}$ Only if it were shown that secular courts became more receptive to such cases would 'forum shopping' by litigants be a sufficient explanation for the trend.

Of greater importance may have been hostility from common lawyers. The rule that pleas of debts and chattels should be heard in the king's courts dated back to the twelfth century. ${ }^{94}$ Common lawyers did not oppose the church's having any jurisdiction over breach of faith. Instead they identified two permissible types of case: a pure kind and a mixed kind. ${ }^{95}$ The former was confined to correcting the sin through corporeal penance. The latter was allowable only

${ }^{88}$ HALS, ASA7/2, fols $67^{\mathrm{v}}, 68^{\mathrm{v}}$.

89 TNA, SP1/99, fol. $199^{\mathrm{r}}$ (L\&P 9: 1071).

90 Chris Briggs, 'The Availability of Credit in the English Countryside, 1400-1480', Agricultural History Review 56 (2008), 1-24, at 19-24.

${ }_{91}$ Craig Muldrew, The Economy of Obligation: The Culture of Credit and Social Relations in Early Modern England (Basingstoke, 1998), 199-271.

92 BL, MS Add. 24435, fol. 2v ; Baker, OHLE, 6: 855.

93 Wunderli, London Church Courts, 105; Tucker, Law Courts, 116-21, 333.

94 Constitutions of Clarendon, c. 15.

95 McGlynn, ed., Rights and Liberties, 125; Anthony Fitzherbert, La Graunde Abridgement (London, 1577), fol. 194' ('Consultacion', plea 5, per Solyard). 
where the thing in question was spiritual. Although the church's office jurisdiction was more tolerable, its instance jurisdiction was not rejected outright. What was unacceptable was compelling a party to perform a 'temporal act', such as paying a debt, which pertained to the king's courts. ${ }^{96}$ The crown had long offered subjects the writ of prohibition as a means of preventing church courts from hearing improper cases. Lyndwood had, however, advised only technical compliance. He recommended the careful drafting of the libel (or bill of complaint to a church court) as a way of eluding the writ. Common lawyers remarked upon the uninformative nature of libels. ${ }^{97}$ The issue was therefore whether the rule could now be enforced more effectively than in the past.

The statutory offence of praemunire provided the solution by allowing the common-law courts to decide the real issue. Praemunire referred in an open-ended way to any activity that infringed the crown's jurisdiction. Over the fifteenth century, it had come to be applied to church courts within the realm, as well as to those outside it. ${ }^{98}$ Hence a husbandman who sued in Norwich's consistory court for breach of a monetary obligation could be prosecuted by the other party, who alleged that 'the matiere shulde be determyned at the Commen Lawe acordyng to the said statute and not in the spirituell courte'. ${ }^{99}$ The number of praemunire actions brought in the court of King's Bench picked up from the mid-1490s, just as breach of faith cases peaked. Praemunire actions for hearing pleas involving debts and chattels (which would have comprised most breach of faith cases) were concentrated in the first decade of the sixteenth century. ${ }^{100}$ They covered church courts in nine dioceses: Canterbury, Durham, Exeter, Hereford, Lincoln, London, Norwich, Salisbury and York. Joining litigants as defendants were judges, proctors, registrars and summoners. They included the

\footnotetext{
96 Year Books, Pasch. 38 Hen. VI, plea 11; Mich. 20 Edw. IV, plea 9; Trin. 12 Hen. VII, plea 2; Baker, ed., Reports of Henry VIII, 1: 235; Fitzherbert, Nouel natura breuium, fol. $45^{\mathrm{r}}-\mathrm{v}$.

97 Lyndwood, Provinciale, 315o; Year Books, Trin. 22 Edw. IV, plea 47; J. H. Baker, ed., The Notebook of Sir John Port, SelS 102 (London, 1986), 18.

98 Daniel F. Gosling, 'Church, State, and Reformation: The Use and Interpretation of Praemunire from its Creation to the English Break with Rome' (PhD thesis, University of Leeds, 2016), 120-57.

99 TNA, C1/124/70 (1486x1493).

100 Gosling, 'Church, State, and Reformation', 162-5, 213-16.
} 
chancellors of Lincoln and Norwich dioceses, the commissary of St Paul's Cathedral and the official of the archdeacon of Wiltshire. ${ }^{101}$ At the Huntingdonshire quarter sessions in 1506, the commissary of Ramsey Abbey was indicted simply for asking a defendant to swear that she did not owe anything. ${ }^{102}$

Praemunire actions presumably deterred parties from bringing breach of faith cases and church courts from hearing them. Even though actions almost never resulted in convictions, the expense, inconvenience and worry must have been considerable. Whether a church court would still compel payment of a debt may also have influenced potential litigants. From 1500, Canterbury's consistory court stopped ordering payment of debts and instead awarded penance. So doing brought the court's practice into conformity with common law, just as praemunire actions intensified, but made it less attractive. The volume of cases in 1511 was one-third of what it had been in 1499. Then, in 1511, the consistory court resumed ordering payment of debts; perhaps litigants had by then found other forums, for the number of cases did not recover. ${ }^{103}$ Nevertheless breach of faith cases continued to be heard into the 1530 s. ${ }^{104}$ Descriptions are often too brief to tell what was being sought. A libel of 1534 insisted that it sought nothing but canonical correction. ${ }^{105}$ In 1532, the consistory court of Durham dismissed a case brought by the city's tailors on account of its civil character, but heard another concerning payment for a horse three years later. ${ }^{106}$ Still, breach of faith was by then only a vestige of what it had been a half-century before.

101 TNA, KB27/973, rotulet 35' ; P. R. Cavill, “"The Enemy of God and His Church”: James Hobart, Praemunire, and the Clergy of Norwich Diocese', JLH 32 (2011), 127-50, at 136-43; TNA, KB27/960, rotulet 77; KB27/994, rex rotulet 3.

102 TNA, KB9/442/112-14.

103 Woodcock, Medieval Ecclesiastical Courts, 90-1; Helmholz, 'Assumpsit', 424; Wunderli, London Church Courts, 105-7.

104 BIA, CP.G.252; CP.G.293; TNA, C1/632/20; Alice M. Cooke, ed., Act Book of the Ecclesiastical Court of Whalley, 1510-1538, Chetham Society n.s. 44 (Manchester, 1901), $182,184$.

105 BIA, CP.G.239. Perhaps this statement was made because the plaintiff had a common-law remedy in the action of account.

106 James Raine, ed., Depositions and other Ecclesiastical Proceedings from the Courts of Durham, extending from 1311 to the Reign of Elizabeth, SS 21 (London, 1845), nos 39, 45. 
The curtailment of ecclesiastical jurisdiction was based on commonlaw principles, but these were not secular ones. For John Hales, a vision of divine law infusing all present-day legal systems rationalized restricting what cases church courts could hear. In his reading at Gray's Inn in 1514, Hales explained why churchmen should not hear many breach of faith cases:

In this realm there are two manners of jurisdiction, namely spiritual jurisdiction, which is derived from the pope and the spirituality, and the temporal jurisdiction, which is given to the king and the temporality. And the two jurisdictions resemble two swords (deux espes scilicet swordes) and each ought to aid the other. The jurisdictions have a certain determination, over which matters they have authority. Each of them ought to keep to its own and not meddle with the jurisdiction of the other. The spiritual jurisdiction commences with the spiritual commands such as matrimony, bastardy, bigamy, etc. And other matters do not appertain to those men who do not have knowledge of the division of things, so no more debt, covenant or contract with oath. These do not appertain to such men because they do not know when a contract is good and when it is not, which could be through a nude pact (ex nudo pacto) with an oath and still it is not a contract in our law, and therefore they ought not to meddle with that. ${ }^{107}$

Hales barred ecclesiastical jurisdiction because churchmen regarded an oath as validating an agreement. For common lawyers, however, it was the reciprocal benefit, or quid pro quo (what would come to be called the 'consideration'), that did so. Hence a nude pact, or promise without mutual benefit, was not enforceable. ${ }^{108}$

Unlike civil law (from which the term came), canon law did enforce a nude pact. While few breach of faith cases seem likely to have concerned nude pacts, the existence of a reciprocal inducement was, strictly speaking, irrelevant to church courts in determining the validity of a promise. ${ }^{109}$ Significantly, common lawyers maintained that a nude pact was not actionable, rather than that it was in no

\footnotetext{
107 Gray's Inn, MS 25, fol. $292^{\mathrm{r}}$.

108 Baker, ed., Reports of Caryll, 2: 514; D. J. Ibbetson, A Historical Introduction to the Law of Obligations (Oxford, 1999), 80-3; Baker, OHLE, 6: 813-17, 862-8.

109 Helmholz, 'Assumpsit', 414-16; Helmholz, Spirit, 161-4. A plaintiffs interest in the contract being performed could be stated explicitly: Cooke, ed., Act Book of Whalley, 48.
} 
way binding. In his Doctor and Student of 1528 and 1530, Christopher St German explained why. With a quid pro quo, it was reasonable to infer an intention to be bound; with a nude pact, only its maker could know what his or her intention had been. A nude pact could be binding in the internal forum of conscience, over which, however, neither legal system should exercise cognizance. ${ }^{110}$ This was a bold attempt to dictate to the church the partition between the 'penitential' and the 'contentious' forums. ${ }^{111}$

Breach of faith in church courts could be remedied as breach of contract at common law. But rules restricted what kinds of contract would be enforced. An action of covenant redressed failure to perform a promise, but only when the agreement was in writing. An action of debt did not require written documentation, but permitted defendants to wage their law (that is, deny by swearing alongside oath-helpers). ${ }^{12}$ Wager relied on litigants' consciences preventing them from forswearing; though church courts were barred for trying false wager as perjury, Chancery might provide relief. ${ }^{113}$ A new remedy for verbal agreements was, however, emerging: the action of assumpsit. As a species of trespass, assumpsit did not permit wager, and it allowed agreements to be proved orally. By 1400, assumpsit was available for misfeasance (partial or inadequate performance), for which no other remedy existed. Over the fifteenth century, assumpsit remained unacceptable for nonfeasance, because it would have duplicated existing actions. ${ }^{114}$ This position began to change around the turn of the sixteenth century. By 1532, the majority opinion in King's Bench favoured assumpsit lying for nonfeasance as well. ${ }^{115}$ Now it could be alleged against the church's jurisdiction

110 St German, Doctor and Student, ed. Plucknett and Barton, 227-33; A. W. B. Simpson, A History of the Common Law of Contract: The Rise of the Action of Assumpsit, rev. edn (Oxford, 1987), 376-96.

111 Lyndwood, Provinciale, 327r, 337g.

112 Simpson, History of Contract, 3-196; Ibbetson, Introduction to Obligations, 24-38; Baker, OHLE, 6: 819-32, 835-7.

113 TNA, C1/369/92; C1/410/46; C1/713/22; St German, Doctor and Student, ed. Plucknett and Barton, 108-9, 232-3; McGlynn, ed., Rights and Liberties, 163; Norman Doe, Fundamental Authority in Late Medieval English Law (Cambridge, 1990), 150-3.

114 Year Books, Mich. 21 Hen. VII, plea 5; Simpson, History of Contract, 199-315; Ibbetson, Introduction to Obligations, 126-51; Baker, OHLE, 6: 757-60, 839-62.

115 Baker, ed., Reports of Caryll, 2: 417; J. H. Baker, ed., The Reports of Sir John Spelman, 2 vols, SelS 93-4 (London, 1977-8), 1: 4-6. 
that '[a]ctions upon ... breking of promisez lye at the kinges cort.' 116 Thereafter assumpsit became the principal action for breach of contract.

The action of assumpsit expanded as breach of faith declined in church courts. The one did not directly supplant the other: assumpsit was uncommon before the mid-sixteenth century, and most breach of faith cases concerned sums below the forty-shilling minimum in the central royal courts. ${ }^{117}$ Nevertheless the coincidence suggests some cross-fertilization. Common lawyers would not have acknowledged any connection. In their perspective, lack of relief at common law did not legitimate the exercise of ecclesiastical jurisdiction: hence confining church courts within their proper (and historic) bounds did not oblige the profession to devise compensatory remedies. ${ }^{118}$ Yet in the first decade of the sixteenth century the common law borrowed ecclesiastical models in order to develop a rival jurisdiction over defamation and used the same form of trespass action as assumpsit to do so. ${ }^{119} \mathrm{Up}$ to a point, an action of assumpsit resembled breach of faith. ${ }^{120}$ Assumpsit was an action for breach of promise, for which it awarded compensation. A stress on the promise (as opposed to the contract) mirrored the priority of the faithful promise in breach of faith cases. ${ }^{121}$ The faithful element in assumpsit was, however, superfluous: it did not substantively affect the pleading, nor did it turn the promise into a sacred obligation. Defendants opposed on the grounds of not having made a simple promise, rather than not having pledged their faith. ${ }^{122}$ Chancery's burgeoning jurisdiction over unsworn agreements thus seems equally likely to have spurred the development of assumpsit. ${ }^{123}$

\footnotetext{
116 McGlynn, ed., Rights and Liberties, 162.

117 Helmholz, 'Assumpsit', 409-10; Wunderli, London Church Courts, 107, 153.

118 St German, Doctor and Student, ed. Plucknett and Barton, 76-7, 144-5, 232-3.

119 R. H. Helmholz, ed., Select Cases on Defamation to 1600, SelS 101 (London, 1985), lxxii, 42; Ibbetson, Introduction to Obligations, 112-25.

120 Helmholz, 'Assumpsit', 413-28; Ibbetson, Introduction to Obligations, 135-40.

121 Baker, ed., Reports of Spelman, 1: 5; Cooke, ed., Act Book of Whalley, 47-8.

122 Lyndwood, Provinciale, 108o, 271dd; Simpson, History of Contract, 214, 574-9. King's Bench and Common Pleas later diverged over whether a promise could be implied or had to be expressed: Baker, OHLE, 6: 869-74.

123 Fitzherbert, Graunde Abridgement, fol. $12^{\mathrm{r}}$ ('Accion sur le case', plea 45); Year Books, Pasch. 8 Edw. IV, plea 11; Pasch. 7 Hen. VII, plea 2; Simpson, History of Contract, 275-80.
} 
To take stock, a conjectural explanation of the decline of breach of faith cases might go something like this. Most litigants were not really seeking canonical correction, but rather payment and performance, which were, however, the remedies that church courts reluctantly felt less able to offer. Put off by the possibility of praemunire actions, most litigants turned instead to local courts and later to the central common-law courts as well. Common lawyers thus circumscribed the remit of breach of faith in a way that rendered it significantly less appealing. The church's office jurisdiction over perjury may have been too reliant upon its instance jurisdiction to thrive separately. In 1540, it was alleged that London's diocesan courts 'durst not' prosecute even perjury committed in front of them 'for feare and drede of A preminire'. ${ }^{124}$ Common lawyers provided the impetus behind this development, not only because they wished to take a slice of the church courts' business, but also because they objected to the perceived usurpation of royal jurisdiction and had developed an effective instrument to do something about it. Intriguingly, the same trend occurred a little earlier in France, where civil lawyers adopted a jealously royalist perspective: a peak in the church's cognizance of debt in the mid-fifteenth century, followed by a decrease that became pronounced after the turn of the century. ${ }^{125}$ By contrast, in contemporary Scotland, where a lay legal profession was only beginning to develop, the church's jurisdiction continued to be exercised unchecked. ${ }^{126}$

\section{VI}

The decline of breach of faith occurred before the break with Rome. The pressure applied to the church in the years immediately preceding did, however, prompt attacks on a facet of ecclesiastical procedure connected to perjury. As well as enforcing oaths, church courts took oaths from those appearing before them. The preliminary oath entailed an open-ended commitment to answer truthfully and to comply with judgments; hence some individuals resisted taking it, at least before knowing the articles against them. Refusal could result in either

\footnotetext{
124 TNA, STAC2/32/151.

125 Tyler Lange, Excommunication for Debt in Late Medieval France: The Business of Salvation (Cambridge, 2016), 76-219.

126 Simon Ollivant, The Court of the Official in Pre-Reformation Scotland: Based on the surviving Records of the Officials of St. Andrews and Edinburgh, Stair Society 34 (Edinburgh, 1982), 65-6, 86-7, 163.
} 
conviction or excommunication; acceptance could lead to self-incrimination or perjury. ${ }^{127}$ The early evangelical William Tyndale expounded oath-taking in an orthodox manner, adopting Augustine's defence of needful swearing. ${ }^{128}$ Nevertheless he accused judges in church courts of coercing suspects into taking oaths: 'Yf they desyre to knowe their accusers, naye saye they, the mater is knowen well ynough and to moare then ye are ware of. Come laye youre hande on the boke, yf ye forswere your selfe, we shall bringe proves. ${ }^{129}$ Tyndale's caricature captured the perception that defendants were disadvantaged in comparison with those at common law. These criticisms were ventilated in the early 1530s, both in the Commons' Supplication against the Ordinaries (1532) and in the treatises of Christopher St German, to which Thomas More replied. ${ }^{130}$

There were two main dimensions of this criticism. The first was that people did not know the charges against them or their source. In instance cases, defendants had a statutory right to obtain a copy of the libel; in office cases, they could receive a summary of the charges, if they knew to ask for it. ${ }^{131}$ A consultation upon a writ of prohibition in 1527 confirmed that the statute did not apply to ex officio proceedings. ${ }^{132}$ The second element was the oath to tell the truth. It was a canonical principle that 'no one is obliged to betray themselves'; this did not, however, confer an unqualified privilege against selfincrimination, but only protection from being required to reveal hidden faults. The oath could be demanded where a probable cause, grounded in 'public fame', existed. ${ }^{133}$ The two criticisms coalesced because the rationale for imposing an oath might not be apparent

\footnotetext{
127 Margaret Bowker, ed., An Episcopal Court Book for the Diocese of Lincoln, 1514-1520, Lincoln Record Society 61 (Lincoln, 1967), 62, 67; Elvey, ed., Courts of Buckingham, 40; Hale, ed., Precedents, nos 253, 294, 321, 332.

128 William Tyndale, An Exposicion vppon the .V.VI.VII. Chapters of Mathew ([Antwerp, 1533]?), fols $46^{\mathrm{v}}-49^{\mathrm{r}}$; Hadfield, Lying, 115-17.

129 William Tyndale, The Obedience of a Christen Man (Antwerp, 1528), fol. $77^{\mathrm{v}}$.

130 Gerald Bray, ed., Documents of the English Reformation, 1526-1701, rev. edn (Cambridge, 2004), 53-5; John Guy, 'Thomas More and Christopher St German: The Battle of the Books', in Alistair Fox and John Guy, Reassessing the Henrician Age: Humanism, Politics and Reform, 1500-1550 (Oxford, 1986), 95-120.

1312 Hen. V st.1 c.3; Francis Douce, ed., The Customs of London, otherwise called Arnold's Chronicle (London, 1811), 192; TNA, C269/11/17.

132 BL, MS Add. 48012, fols $50^{\mathrm{r}}-51^{\mathrm{v}}$.

133 Lyndwood, Provinciale, 109p, 109r, 113-14f, 312i-k; Thomas More, A Dyaloge [concerning Heresies] (London, 1529), fols 78 ${ }^{\mathrm{r}}-79^{\mathrm{v}}$; Foxe, Actes and Monuments, 2: 1102 , 1118-19; R. H. Helmholz, 'The Privilege and the Ius Commune: The Middle Ages to
} 
to the individual concerned. Hence an examinee might be taken by surprise. A debtor to his parish church was interrogated about nonpayment of personal tithes, perjury in the manor court and usury as well. ${ }^{134}$ George Gower complained that he was deemed to have committed perjury merely for interpreting the subjective term 'famyliarite' differently from the judge. ${ }^{135}$ Put under oath, without knowing their accusers or the evidence against them, and forced to answer 'subtle interrogatories', examinees incriminated themselves, forswore or did both.

Heresy cases proceeded ex officio. ${ }^{136}$ During the prosecutions in the diocese of London in 1528, the requirement to take the preliminary oath produced several refusals: one suspect had to be asked twice, another acceded upon receiving 'wiser counsel', a third agreed once he had heard the articles against him and a fourth only complied after being imprisoned in the stocks in Lollards' Tower. ${ }^{137}$ Interrogation under oath could, in fact, assist a suspect: in 1533, Thomas White of Rye swore that he had never read the books found in his possession nor believed the heresies contained within them, whereupon the judge, 'because he could have no proofs, at least not true ones, against him', admitted White at his request to purgation. ${ }^{138}$ Such examinations tempted people to forswear, as perhaps White did; for that reason, defendants and their witnesses in capital cases at common law did not testify under oath. Examination under oath entrapped others who were seeking to avoid perjury, perhaps 'some simple silly soul precisely standing to the clear testimony of his own well-known conscience'. It was the fear of perjuring oneself that made ex officio prosecution so effective. ${ }^{139}$

the Seventeenth Century', in idem et al., The Privilege against Self-Incrimination: Its Origins and Development (Chicago, IL, 1997), 17-46, at 32-5.

134 HALS, ASA7/1, fol. 54v; Hale, ed., Precedents, nos 277, 315.

135 TNA, SP1/70, fol. $163^{\mathrm{r}-\mathrm{v}}$ (L\&P 5: 1176).

136 Ian Forrest, The Detection of Heresy in Late Medieval England (Oxford, 2005), 68-76, 171-206; Gray, Oaths, 170-85.

137 BL, MS Harley 421, fols $19^{\mathrm{v}}-20^{\mathrm{v}}$.

138 WSRO, Ep.I/10/5, fol. $9^{\mathrm{r}}-^{\mathrm{v}}$.

139 Bray, ed., Documents, 55; Jason Powell, ed., The Complete Works of Sir Thomas Wyatt the Elder, 1: Prose (Oxford, 2016), 303; Shapiro, 'Oaths: Part One', 154-9; R. H. Helmholz, 'Introduction', to idem et al., Privilege against Self-Incrimination, 116 , at $8-9,14-15$. 
What connected St German's criticism of heresy proceedings to his earlier jurisprudential work was a standard of proof. He wished to prevent church courts from reaching within the forum of conscience to discover hidden faults. ${ }^{140}$ Evidence from witnesses, and not that from suspects themselves, should form the basis of prosecution. A particular bugbear of his, therefore, was that, contrary to the normal canon-law bar, in heresy cases the testimony of perjured witnesses was admissible. ${ }^{141}$ From a different religious position, Tyndale agreed: present-day judges compel people 'ether to forswere them selves by the allmightie God and by the holy Gospell ... or to testifie agenst them selves', whereas truly Christian judges would rely on witnesses and leave what could not be proven by their evidence to God. ${ }^{142}$ Such criticism could seem hypocritical. As Thomas More pointed out, interrogation under oath was not confined to heresy trials or even to church courts: it was practised in the conciliar courts and also at common law, for example, by justices of the peace examining suspects. ${ }^{143}$ In 1534 , a statute restricted the grounds on which someone might be cited before an ecclesiastical judge on suspicion of heresy, by requiring a presentment, indictment or accusation. But the legislation said very little about the conduct of a trial and so seems to have left the oath itself unaltered. ${ }^{144}$

The efficacy of examination under oath was thus acknowledged. That is perhaps explicable in the light of the contribution of oathtaking to an undoubted achievement of early Tudor government: reforming the system of taxation. The fixed quotas of fifteenths and tenths were replaced with subsidies whose yields depended on individuals' sworn self-valuations. The requirement for the assessment of

140 St German, Salem and Bizance, sigs F4v ${ }^{\mathrm{v}}, \mathrm{F} 8^{\mathrm{v}}$.

141 Ibid., sig. G6v , citing VI 5.2.8 (CICan, 2: 1072); Lyndwood, Provinciale, 114f; E. D. Stone and B. Cozens-Hardy, eds, Norwich Consistory Court Depositions, 14991512 and 1518-1530, Norfolk Record Society 10 (n.pl., 1938), no. 228; Henry A. Kelly, 'Inquisition, Public Fame and Confession: General Rules and English Practice', in Mary C. Flannery and Katie L. Walter, eds, The Culture of Inquisition in Medieval England (Cambridge, 2013), 8-29, at 15.

142 Tyndale, Obedience, fol. $52^{\mathrm{r}} \mathrm{r}^{\mathrm{v}}$.

143 Thomas More, The Debellacyon of Salem and Bizance (London, 1533), sig. H4 ${ }^{\mathrm{r}}-^{\mathrm{v}}$; BL, MS Lansdowne 639, fols 46 ${ }^{\mathrm{r}}$, 56 ${ }^{\mathrm{r}}$; HL, MS Ellesmere 2652, fol. 10 ${ }^{\mathrm{v}}$; MS Ellesmere 2655, fol. 16 ${ }^{\mathrm{v}}$; Bayne and Dunham, eds, Select Cases in the Council, 33.

14425 Hen. VIII c.14; Stanford E. Lehmberg, The Reformation Parliament, 1529-1536 (Cambridge, 1970), 186-7; Henry A. Kelly, 'Thomas More on Inquisitorial Due Process', EHR 123 (2008), 847-94, at 882-9. 
one's wealth to be given under oath was introduced in the subsidy act of 1514, which John Hales drafted in the same year that he read at Gray's Inn. ${ }^{145}$ The orchestration of oath-taking reached a new pitch in the general proscription of $1522 .{ }^{146}$ Of this military and fiscal survey and similar expedients William Tyndale demanded, 'How many thousandes forsware them selfes?' 147 Tyndale was not complaining about the revenue lost through underassessment, but rather about the occasion given to so many people to commit perjury. In fact, this levy, when combined with a forced loan the following year, raised about $£ 200,000$. Presumably, sworn self-valuation worked because many, in order to avoid perjuring themselves, assessed their wealth accurately. ${ }^{148}$ The survey involved a nationwide organization of commissioners, instructions on how oaths should be imposed and the tailoring of texts to different groups. Perhaps it became a model for the succession and supremacy oaths that the crown would demand in the next decade. ${ }^{149}$ This resort to oaths to enforce the break with Rome was a significant, but logical, extension of early Tudor policy.

\section{VII}

There is thus an irony that as oaths became more important to public life after the break with Rome, so the circumference of perjury contracted. The revision of canon law drafted in the mid-1530s restated the traditional view and hence did not clarify the extent of the church's effective jurisdiction over perjury. ${ }^{150}$ In 1541, Edward Hall (the chronicler) gave a reading at Gray's Inn in which he sought to integrate ecclesiastical law into contemporary common law. Hall's eighth lecture considered the church courts' claim to punish usury, perjury and defamation. ${ }^{151}$ Each was a crime over which the church had exercised fuller jurisdiction in 1485 than it did by 1541 on

\footnotetext{
1455 Hen. VIII c.17; Roger Schofield, Taxation under the Early Tudors, 1485-1547 (Oxford, 2004), 19, 88, 90.

146 J. J. Goring, 'The General Proscription of 1522', EHR 86 (1971), 681-705.

147 Tyndale, Obedience, fol. 39 ${ }^{\mathrm{r}}$; Tyndale, Practyse, sigs G3 ${ }^{\mathrm{v}}-\mathrm{G} 4^{\mathrm{r}}$.

148 As is suggested in a letter of 1528 from Archbishop Warham: Henry Ellis, ed., Original Letters, illustrative of English History: Third Series, 4 vols (London, 1846), 2: 31-2 (L\&P 4/2: 4631).

149 L\&P 3/2: 2484-5; L\&P, Addenda, 1/1: 410; Gray, Oaths, 51-115.

150 Gerald Bray, ed., Tudor Church Reform: The Henrician Canons of 1535 and the Reformatio legum ecclesiasticarum, CERS 8 (Woodbridge, 2000), 24-5.

151 McGlynn, ed., Rights and Liberties, xlv-xlix, 176-9.
} 
account of inroads by secular law. ${ }^{152}$ The lecture gave examples of broken oaths that were perjury in one law, in both or in neither. Hall seems to have been trying to assimilate the canon- and common-law definitions of perjury, the former relating to any legitimate oath and the latter to an oath sworn before a court. This endeavour may explain Hall's category of perjuries committed at common law, but not punishable by it. Although the text breaks off here, it does not look as though Hall envisaged the church courts stepping in under these circumstances. Hall's lecture thus shows the challenge of reflecting society's broad understanding of perjury within a narrower legal framework.

In retrospect, the church's quondam jurisdiction over breach of faith has seemed an unnatural intrusion into the secular sphere that would inevitably disappear. Objectively, ecclesiastical cognizance of spiritual actions, as oaths were, appeared perfectly fitting; the problem was that, taken to its logical conclusion in a society where oath-taking was so widely practised, this jurisdiction had encompassed too much. Perjury in early Tudor England thus provides a small, local manifestation of a vast, transhistorical issue: the appropriate manner through which the church (as institution, personnel and abstraction) should relate to the law, whether through independent codes and courts, through co-option into the activities of other legal systems or through spiritual guidance for participants in the legal process. Over the early Tudor period, the crown assumed greater responsibility for the supervision of justice within its domain. More concertedly than in the past, it overrode different legal systems and subjugated autonomous jurisdictions. Royal authority enabled greater coordination and orchestration between ecclesiastical and secular law, albeit not necessarily on the church's terms. Ideas derived from canon law influenced proceedings in the conciliar courts, where perjury was increasingly being prosecuted. Yet, in consequence, a concern with the spiritual condition of the individual receded, and perjury thus became more like other crimes in royal courts: an offence against God, the king and his subjects, rather more than against oneself. Early Tudor England hardly secularized perjury, but perhaps did begin to laicize the concept.

In a pattern observable with certain other offences, after a midcentury hiatus the common law expanded to fill the gap left by the curbing of ecclesiastical jurisdiction during the early Tudor period.

152 Baker, OHLE, 6: 781-99, 832-5; Helmholz, OHLE, 1: 379-82, 593-6. 
It did so in part by naturalizing aspects of canon and civil law. The statute of 1563 that extended the definition of perjury to include witnesses possibly drew upon the revision of canon law undertaken in the previous decade. ${ }^{153} \mathrm{Had}$ this revision been adopted and also implemented, ecclesiastical jurisdiction over perjury would once more have been considerable. Instead, it dwindled to perjury committed before church courts, over which the clergy were even denied exclusive cognizance. ${ }^{154}$ While a staunch defender of the ecclesiastical system could insist that the broader jurisdiction was merely in abeyance, it never revived. ${ }^{155}$ Other types of litigation drove the recovery of business in church courts. ${ }^{156}$ In 1581, jurors convicted of perjury in Star Chamber were ordered to wear papers at the assizes and there listen to a sermon, so that 'by the preacher they mighte be towched in conscience'. ${ }^{157}$ What endured was the church's extralegal role of exhortation and instruction, or perhaps we should rather say its capacity to appeal to the individual's internal forum. Thus our modern, attenuated definition of perjury, as an offence confined to the courts, may be traced back ultimately to early Tudor England.

153 Bray, ed., Tudor Church Reform, 548-55; 5 Eliz. I c.9; Michael D. Gordon, 'The Perjury Statute of 1563: A Case History of Confusion', Proceedings of the American Philosophical Society 124 (1980), 438-54, at 448-52.

154 Francis Clerke, Praxis (London, 1684), 178-9; Helmholz, ed., Select Cases on Defamation, 82; James Dyer, Les Reports (London, 1688), fol. 302 ; BL, MS Lansdowne 639, fol. 75' ; Michael D. Gordon, 'The Invention of a Common Law Crime: Perjury and the Elizabethan Courts', AJLH 24 (1980), 145-70, at 158-60.

155 Richard Cosin, An Apologie for Sundrie Proceedings by Iurisdiction Ecclesiasticall (London, 1593), pt 1, 47-52.

156 R. B. Outhwaite, The Rise and Fall of the English Ecclesiastical Courts, 1500-1860 (Cambridge, 2006), especially 15-22, 64-70.

157 HL, MS Ellesmere 2768, fol. 46 ${ }^{\mathrm{r}}$; Barbara J. Shapiro, 'Oaths, Credibility and the Legal Process in Early Modern England: Part Two', Law and Humanities 7 (2013), $19-54$, at $39-48$. 